\title{
LA CONCIENCIA SEMIÓTICA DEL ESPECTADOR
}

Tatiana Sorókina*

\section{A manera de preludio}

$$
\text { Con el medio impreso surge la }
$$
posibilidad de plasmar el teatro en el papel, suspendiendo el ejercicio de actores o, más bien, transfiriéndolo a una actuación imaginaria. En este momento, el espectador se convierte en un lector totalmente encomendado, quien interpreta y plenamente recibe a su cargo la acción teatral. Si el teatro actuado (una manifestación artística oral) es improvisable, ${ }^{1}$ volátil, y su realización depende de muchos sujetos y variables, la expresión teatral escrita obedece principalmente al lector y se relaciona con sus habilidades: imaginativa, exegética, artísticoestética, intelectual, entre otras. El espectáculo en vivo se convierte en uno virtual o ficticio.

Con lo anterior intentamos justificar nuestra propia perspectiva de lector, por la que se optó al aproximarse a la obra de dos escritores mexicanos: Jorge Ibargüengoitia y Vicente Leñero. Asimismo anunciamos que bajo nuestra observación no se encuentra el teatro en vivo, sino un discurso teatral, fijado y conservado en las páginas impresas, y permite ser, releer, fantasear el espectáculo e, igualmente, vivirlo.

También es importante hacer hincapié en lo siguiente. En este estudio nos atrae el suceso teatral desde la perspectiva de razón pragmática. Por lo tanto aquí no nos interesa la historia de los autores, ni

\footnotetext{
* Universidad Autónoma Metropolitana-X.

${ }^{1}$ Dentro de las reglas teatrales establecidas.
} 
la historia de su obra; tampoco el análisis de sus piezas, ni su comparación. Únicamente nos explayamos en torno a un hecho artístico situado en un sistema cultural concreto cuyo lugar central ocupa el espectador.

\section{Obertura}

En la literatura universal contemporánea no abundan los autores que se dedican al teatro exclusivamente. Tampoco en la literatura mexicana; se puede mencionar a los escasos dramaturgos que claramente se distinguen por su preferencia dramatúrgica, como, por ejemplo: Rodolfo Usigli, Emilio Carballido o Héctor Mendoza. La mayoría de las piezas teatrales sale de plumas de los escritores que combinan diferentes géneros del arte literario, y, además, practican el periodismo.

Jorge Ibargüengoitia y Vicente Leñero son conocidos por su obra bastante diversa, si se trata de la tipología de sus escritos: en su repertorio se pueden encontrar novelas, géneros periodísticos, relatos y cuentos. Asimismo, dedicaron un tiempo para componer piezas teatrales. Lo curioso es que ambos -en un momento determinado, aunque por razones diferentes- abandonaron el emplois de dramaturgo. Ibargüengoitia reveló su salida del teatro en un artículo "Oración fúnebre en honor de Jorge Ibargüengoitia", y Leñero advirtió de su alejamiento del teatro al dar el título: Dramaturgia terminal. Cuatro obras a una de sus últimas publicaciones.

En el presente trabajo reflexionamos sobre las piezas de estos dos autores mexicanos, muy distantes por su estilo de expresión teatral, pero con indudable similitud, tal vez no muy explícita y evidente. La semejanza, que se descubre en la postura y la manera realista de escribir el teatro, nos permitió comparar las obras de ambos escritores, aunque en un principio éstos fueron escogidos por antinomia. Ésta, a su vez, permitió acercarnos a la respuesta: ¿por qué los efectos, que sus obras teatrales producen sobre el público, son tan notoriamente desiguales y aun contrarios? En el artículo "Concepto versus apreciación”, Jorge 
Ibargüengoitia manifiesta un desasosiego esbozando así la opinión pública sobre su obra:

Cuando le llevo a un director una obra, nunca tiene el valor de decirme que no le gusta -que sería la verdad-, sino que me dice que al mundo en estos momentos críticos no le interesa el sexo; que los personajes no son reales porque no tienen ideología propia (como si alguien la tuviera); que es muy negativa o que es demasiado positiva... ${ }^{2}$

Por el contrario, todo indica que la suerte de las piezas de Leñero fue diferente tanto en su aceptación por los directores y el auditorio como por la crítica.

\section{$* * *$}

Entre los años setenta y noventa, Yuri Lotman, un famoso teórico de literatura y cultura ruso, planteó y desarrolló una nueva categoría de observación y análisis que llamó semiosfera. ${ }^{3}$ Ésta le permitió unir los elementos de la cultura, el arte, el texto, la conducta y el espacio en un solo sistema semiótico. Creemos que algunos conceptos de su teoría pueden ser aplicados a nuestro caso donde la comparación del teatro de Ibargüengoitia y Leñero permite, aunque a nivel general, esclarecer una diferencia entre ellos en lo que se refiere a su percepción por parte de los espectadores (o lectores).

El concepto de la competencia semiótica ocupa, en nuestra opinión, una de las posiciones centrales en la teoría de semiosfera, ${ }^{4}$ por lo menos, en lo que se lo puede relacionar con el aspecto pragmático

${ }^{2}$ Jorge Ibargüengoitia, El libro de oro del teatro mexicano, 1999, México, El milagro/ IMSS, p. 71.

${ }^{3}$ En ruso, la palabra semiosfera se pronuncia acentuada en la penúltima sílaba (asimismo 'biosfera', 'atmósfera', etc.); es como la utilizó el traductor de la obra de Lotman. Sin embargo, en español presenciamos dos tendencias fonéticas diferentes: hacia una acentuación esdrújula, por analogía con atmósfera, y hacia la pronunciación grave, por analogía con biosfera. El vocablo semiosfera es una invención terminológica de Lotman, por esto también preferimos darle su pronunciación original.

${ }^{4}$ Sobre la teoría de semiosfera v. la obra de Lotman en la bibliografía del presente artículo. 
de la teoría de Lotman, es decir, su aplicación a los fenómenos reales de la cultura. Estos últimos corresponden a la interpretación, a la subjetividad $^{5} \mathrm{y}$, por lo tanto, a la opinión pública; finalmente al propio individuo en el proceso de recibir textos de diversas índoles.

La ineludible condición lingüística del hombre conduce a Lotman a un nivel semiológico de la codificación y descodificación de los signos culturales de índole diferente. "Para existir, el hombre debe añadir a su existencia física una existencia sígnica", como cita Lotman una carta de Lavater a Karamzín. ${ }^{6}$ La misma idea indudablemente se extiende tanto hacia los mensajes verbales como visuales y auditivos.

Esta metamorfosis de codificar-descodificar debe conducir necesariamente a la toma de conciencia semiótica, mediante la cual se realiza una distinción de elementos significativos y no significativos para una realidad circundante. Más aún, la distinción de los significados vuelve "el acto inicial y esencial de toda modelización semiótica de la cultura". ${ }^{7}$ La observación del mundo -y del mundo artístico, en primer lugar-, la reflexión y la intervención comunicativa se basan precisamente en la colisión de las expresiones denotativas y connotativas, en la deliberación de los sentidos. Merece la pena completar que el desarrollo de la conciencia semiótica se vincula directamente con el discernimiento de habilidades discursivas y hermenéuticas, la comprensión y perspicacia del mundo artístico.

El concepto de Lotman adquiere una cualidad más importante si lo empleamos en el medio teatral, pues éste incorpora varios sistemas semióticos en un mismo espacio:

${ }^{5}$ Lo subjetivo en el procesos hermenéuticos lo entendemos en términos relativos, así como P. Ricoeur ("de la misma manera que el mundo del texto sólo es real porque es ficticio, es necesario decir que la subjetividad del lector sólo aparece cuando se la pone en suspenso, cuando es irrealizada, potencializada". En Ricoeur, 2002:109) o U. Eco quien se opone al libertinaje de interpretación, que llama sobreinterpretación o interpretación paranóica ("decidir cómo funciona un texto significa decidir cuál de sus diversos aspectos es o puede ser relevante o pertinente para una interpretación coherente y cuál resulta marginal e incapaz de soportar una lectura coherente". En Eco, 1995:159).

${ }^{6}$ Iuri M. Lotman, La semiosfera III. Semiótica de las artes y de la cultura, 2000, Madrid, Cátedra, (edición de Desiderio Navarro), p. 94.

${ }^{7}$ Ibid., p. 91. 
En realidad, el texto único del espectáculo se compone por lo menos de tres subtextos bastante independientes: el texto verbal de la pieza, el texto de la actuación, creado por los actores y el director y el texto de la conformación pictórico-musical y lumínica. ${ }^{8}$

Se incluyen aquí, por supuesto, los signos prosódicos, espaciales, temporales, de gestos y de trajes. En el teatro, los 'movimientos significativos' se entrelazan entre sí componiendo una realidad artística polifacética y sui generis. $^{9}$

La revelación de los juegos de sentido implica una formación semiótico-cultural que permite separar y disfrutar dos mundos aunque profundamente afines, sin embargo, totalmente distintos. Así, la existencia del hombre alcanza a ser vista desde un enfoque práctico y se complementa por el otro, el de la extensión estética. El ascenso artístico de las emociones e intelecto siempre presenta una disyunción y alternativa para la vida cotidiana. ${ }^{10}$ De esta manera, el 'adiestramiento' cultural no permite que la conducta rutinaria y el sentido común de los individuos intervengan en la percepción de las obras de arte ni los guía en este proceso.

Sin discriminar los significados de diferentes niveles, dos mundos se tropiezan y surgen accidentes ridículos y lamentables. Ibargüengoitia se refirió sarcásticamente a tales casos en el teatro:

Los espectadores ocupan los cuatro lados del escenario, y se supone que esta circunstancia, o cuando menos el pánico que ella produce, es capaz de obligar al actor a compenetrarse más completamente de su papel.

${ }^{8}$ Ibid., p. 76.

${ }^{9}$ Reiteramos que todos estos elementos, visibles en el espectáculo en vivo, también se presentan, pero de manera virtual en la lectura del texto teatral. Aquí, la conciencia semiótica se deriva exclusivamente de lo verbal, de su semántica, mientras que la polivalencia semiótica implica una imaginación activa.

${ }^{10}$ Es lo que se puede ver en la percepción de dos mundos por parte de los niños quienes fácilmente empiezan a percibir el juego como si fuera una realidad no construida. También se puede recordar los casos cuando el impacto emocional fue tan fuerte que las obras artísticas fueron destruidas como si fueran culpables en los hechos nocivos para un grupo o una sociedad completa. 
Lo malo es que el espectador se compenetra más del suyo. Cuando un actor se desmaya en escena, porque así está marcado, nunca falta un espectador compadecido que lo ayuda a levantarse. ${ }^{11}$

En tales accidentes, la idea escénica no corresponde al comportamiento del espectador $\mathrm{y}$-se puede imaginar- no puede ser lograda. La vida y la actuación teatral son dos realizaciones del hombre paralelas.

Probablemente, los desconciertos semiótico-culturales se manifiestan más y con mayor frecuencia cuando el arte se crea a partir de los principios realistas. En el realismo literario (en la modernidad y postmodernidad libresca, el teatro forma parte de este último), la construcción específica de significados se percibe menos que en otras escuelas literarias. El lenguaje artístico se aproxima notablemente a la lengua cotidiana -de hecho, ésta es una de sus metas-y prácticamente la duplica; con esto se pierde el convencionalismo del signo teatral, su artificialidad. Debido a esto, la comprensión y el alcance de las obras se dificultan más. Continuamente los conflictos descritos en la literatura no se perciben como ficticios, y el contenido de una obra realista se confunde con la vida real, se reduce a ella, aun la sustituye borrando los límites del arte.

El teatro realista, al igual que cualquier otro género, contiene ineludiblemente simbología y recursos metafórico-metonímicos propios. Éstos no deben confundirse con la experiencia cotidiana, por el contrario, distancian y sólo aparentan la realidad. El intento de identificación de lo conocido en un espectáculo y su percepción únicamente como un hecho real hace confundir al espectador y disminuye el valor artístico de la obra, pues no se le atribuye ningún significado connotativo, adicional al significado directo.

En este sentido, es ilustrativo comparar lo propio con lo ajeno, ya que la situación semiótica cambia cabalmente. Así, el arte de otras culturas se considera plenamente estipulado (no originado naturalmente) y se piensa en términos de arte propios: "la convencionalidad del arte

${ }^{11}$ Jorge Ibargüengoitia, El libro de oro..., op. cit., p. 115. 
extraño hace que se lo perciba como un texto cifrado, comprensible mediante la 'traducción' del mismo al sistema habitual". ${ }^{12}$ La búsqueda y comprensión de los sentidos nuevos, entonces, se pone como una meta consciente.

El teatro de Ibargüengoitia y Leñero, a pesar de una tendencia realista muy marcada, sólo puede ser desenmascarado desde una perspectiva semiótica convencional y comprendido a través de una indagación sobre los significados profundos por encima de los fácilmente percibidos en la superficie dialogal de las obras. Adelantando, tal parece que los métodos artísticos con que se logra el convencionalismo en estos dos autores, son diferentes $y$, debido a esto, las expectativas del público (o del lector) varían visiblemente.

\section{Retratación dramatúrgica}

Las escuelas realistas yacen sobre la idea de la verdad. La literatura pretende reflejar la vida de manera fiel y certera; de ahí, la sensación de que lo sucedido o descrito no es sino una copia de los acontecimientos reales. Esta credibilidad se logra de modos distintos; uno de los más tradicionales es retratar. A través de retratos, los lectores, oyentes o espectadores se identifican con los personajes o se les oponen hasta que, a veces, la identificación se vuelve dramáticamente ridícula. El retrato, dice Lotman, "desempeña el papel de un testimonio documental de la autenticidad del hombre y de su representación imaginal [izobrazheniia $]^{13 "} .{ }^{14}$ La realidad ficticia se percibe como verdadera, si el objeto de retratación es identificable como real por aquel que lo contempla.

A la vez es difícil hablar sobre el concepto de retrato en el ambiente teatral. Éste tiene desenvolvimientos diferentes en comparación con la

${ }^{12}$ Iuri M. Lotman, La semiosfera II. Semiótica de la cultura, del texto, de la conducta y del espacio, 1998, Madrid, Cátedra (edición de Desiderio Navarro), p. 240.

${ }^{13}$ El sustantivo izobrazhenie ('presentación', 'imagen') derivado del verbo con la misma raíz de 'presentar' o 'representar' puede ser traducido como imagen -en vez de representación imaginal-, aunque no se origina en el verbo ni significa acción.

${ }^{14}$ Iuri M. Lotman, La semiosfera III..., op. cit., p. 24. 
narrativa o las artes plásticas. Aquí la retratación de los personajes supera a la palabra: aquí el gesto, sonido, movimiento, vestido o el mismo escenario construido juega un papel complementario. Entonces, en la teoría dramatúrgica la noción de retrato, que sigue existiendo muy útil para el análisis, tiene que entenderse con ciertas modificaciones.

El quid del retrato, como recurso artístico ${ }^{15}$ en general, se encuentra en su naturaleza descriptiva. El autor hace descubrir a sus personajes pintando con diálogos sus caracteres, rasgos físicos, emocionales o intelectuales; todo lo que integra la imagen de cada uno. Asimismo, se retratan grupos de personas, sociedades completas, que a su vez conducen a la descripción de comportamientos, hábitat, arquetipos intelectuales y espirituales. De igual manera, se crean los verdaderos cuadros de un período histórico o cultural, de las acciones y actividades mismas. Es difícil asociar las últimas con el retrato propiamente dicho, sin embargo estos cuadros verbales cumplen la misma función descriptivo-retratística.

En el teatro el autor no delinea prácticamente nada de manera directa ${ }^{16}$ no interviene como lo hace en la narrativa: el retrato emerge de los discursos dialogales. Inclusive se podría decir que los personajes se retratan a sí mismos. También en el escenario durante la actuación frente al público se moldean las imágenes de la época con sus ademanes, actitudes y acciones. En este sentido el concepto de retrato se modifica considerablemente extendiéndose hacia el de descripción, sin perder la cualidad de ser una especie de espejo. Mirar o, más bien, mirarse en el espejo teatral es cometido del receptor del espectáculo.

\section{Ibargüengoitia y Leñero}

Los dos escritores escogidos pertenecen, reiteramos, a la corriente realista, ambos reflejan la realidad en sus obras teatrales y mediante

\footnotetext{
${ }^{15}$ Sin duda, no es el único.

${ }^{16}$ El papel de didascalia y acotaciones de una pieza teatral por lo general no es significativo.
} 
éstas. Sin embargo, se puede notar que sus enfoques de observación están orientados hacia objetos diferentes. En el lienzo escénico de Ibargüengoitia se plasman situaciones, acontecimientos. No sucede prácticamente nada en el escenario, no hay actividad dinámica: toda la atención del dramaturgo se enfoca hacia el asentir y replicar de los héroes. Éstos, a su vez, sólo existen en el escenario; aún más, el discurso de las obras no presta ninguna información para imaginarlos fuera del drama. El espectador presencia absolutamente todo, más bien, el escenario se vuelve un todo, completo y autosuficiente, como si divisara un cuadro pictórico. Nos referimos prácticamente a toda la obra de Ibargüengoitia, trátese de Susana y los jóvenes, Clotilde en su casa, Llegó Margó o Ante varias esfinges.

En las piezas de Leñero ocurre algo diferente. Mediante los diálogos se describe el pasado, presente y futuro de los personajes. La palabra replicada enuncia los movimientos de la vida de los protagonistas, expresa el dinamismo de sucesos. No es casual que en su mayoría sean deportistas o también pertenezcan a la estirpe reportera. La trama refleja acción, rebasando los marcos del concepto de retrato. En realidad, éste representa como secuencia de retratos. ${ }^{17}$ En las piezas Pelearán diez rounds, Nadie sabe nada, El andamio, Caminata, Violación, entre tantas se trata de personajes cuya profesión se relaciona con la acción y el movimiento en el tiempo.

Asimismo, en los dos escritores se observa un manejo diferente del discurso dialogal, al igual que se exponen varios ángulos y temas de la realidad. En Leñero la palabra cumple función de conducto o canal de transmisión, es decir, se encuentra en el segundo plano del mismo hecho artístico. En el centro de la obra confluyen los sucesos y acciones, y el mayor interés se encierra en lo que ocurre con los personajes o en las causas de su comportamiento. Es demostrativo que Leñero recurre cuantiosamente a las acotaciones, a las intervenciones instructivas de autor, donde casi relata pormenorizadamente los episodios:

\footnotetext{
${ }^{17}$ Algo semejante se puede observar en la sucesión de los cuadros cinematográficos.
} 
Rosamaría abre su sombrilla y se aleja por la calle. Pepe la sigue un momento con la mirada y luego mira con impaciencia a Vecina. Ésta se vuelve hacia el frente, pero sin soltar la bocina. Está escuchando a su interlocutor. Vecina mira a Pepe, comprende su impaciencia, y con los dedos le hace una señal de 'un momentito'. Ni Pepe ni Vecina parecen reconocerse luego de su fugaz encuentro en el edificio, el día anterior (Nadie sabe nada).

O:

A duras penas, Pepe consigue librarse de Toño ayudado por Mesero que empella al borracho. Toño se sacude a Mesero y se dirige a la pista. Intenta bailar con una de las ficheras, pero se desploma y cae tendido en una orilla de la pista. Ahí se queda durante toda la escena. Las parejas bailan, casi pisándolo. Nadie se compadece de él. Pepe localiza a Moctezuma Peón y se dirige a su mesa. El policía lo invita a sentarse (ibid.).

Las réplicas de los personajes prácticamente no se distinguen detrás de las descripciones de la acción. La misma tendencia se observa en los diálogos de Leñero. Éstos frecuentemente se interrumpen por las acotaciones del autor. En este sentido es interesante la mini-pieza Caminata donde todos los personajes (Marchistas 10, 12, 30 y 9) pronuncian repetidamente la única frase: 'Tengo que ganar'. La trama (lo observado durante la caminata) surge en las aclaraciones del autor quien cuenta (al lector) lo que acontece alrededor de esta frase.

Por el contrario, a Ibargüengoitia no le interesa describir los sucesos ni pretende revelar las acciones de los personajes. En primer plano coloca su actividad verbal y no lo que se denomina por ésta. En las conversaciones -retrativamente estáticas $-{ }^{18}$ donde no pasa nada, únicamente se muestran las figuras de los interlocutores:

${ }^{18}$ Aquí por medio del término estatismo no se valoran ni se justiprecian los diálogos, simplemente se indica el carácter inmovilizante del lenguaje de los personajes. Sin duda alguna Ibargüengoitia lo utiliza como un recurso deliberado. 
Carrasco.- ¿A qué vinimos?

Tacubaya.-A visitar, buey.

Pablo.- ¿Tienes mucho que hacer?

Carrasco.- Mucho.

Tacubaya.- Nosotros somos gente muy ocupada. Ahora deberíamos estar en La Palma, tomando cerveza. ¿Verdad?

Carrasco.- No. Es hora de jugar al ajedrez.

Tacubaya.- ¿Sabes qué cosa se me ocurre? No sé, no estoy muy seguro.

Pablo.- ¿Qué cosa se te ocurre?

Tacubaya.-Que debe uno de buscar una mujer de caderas anchas. Mide dos cuartas en el espacio. Así, como esto... (Susana y los jóvenes).

La no-acción de los diálogos se acentúa, y la esencia de la obra ibargüengoitiana en general puede ser averiguada detrás de las indagatorias: ¿Cómo son los personajes? ¿Por qué son así? ¿De qué hablan realmente?

\section{Narratividad teatral}

La consideración de dos planos (palabra y acción) conduce a la diferenciación de los autores desde otra perspectiva, la de la historia. La acción, en el sentido de sucesión de hechos y peripecias, se relaciona directamente con el género narrativo. Últimamente el término 'narración' se usa sobrecargado de sentidos. Tal parece que le empezaron a agregar significados arbitrariamente acercándolo con términos tales como 'prosa', 'texto'y 'discurso' (también utilizados con poco rigor). En la conocida definición de 'contar, relatar' sólo enfatizamos el distintivo atributo cronológico, sin el cual las historias narradas simple y sencillamente no existen.

El origen de los mitos, leyendas, relatos, cuentos, anécdotas, chismes y otras narraciones se encuentra precisamente en la descripción de acciones y sucesos que pasan uno tras otro y se alternan en el tiempo. (Puede acotarse que, en sentido estricto, el retrato ocupa una 
posición contraria, aun antagónica, ya que excluye la noción de tiempo y, así, carece de desarrollo y proceso, aparece estático y prescinde de cualquier movimiento.)

\section{Leñero}

El teatro pertenece a un género verbal ${ }^{19}$ específico en comparación con otros del mismo nivel jerárquico como poesía y prosa (o narrativa). ${ }^{20}$ Sin embargo, también puede incluir elementos narrativos de acción. La obra de Leñero lo ilustra bastante claro. Como ejemplo al azar tomemos la primera pieza del ciclo 'Los perdedores', El andamio.

La trama dialogal refleja la historia del Tío Sergio, su pasado y presente; deja abierto el futuro, pero lo anuncia. Antes jugó al beis con los Cafetaleros en Córdoba y con los Diablos Rojos de México; era pícher y recuerda varias peripecias y personas relacionadas con su pasado deportivo. En este período se enfermó su mamá (a quien, hace tiempo la abandonó el padre del Tío Sergio), por esto su carrera de béisbol se acabó ("Ahora ya no voy más que a ver los partidos, cuando juegan los Diablos Rojos"). Todo esto lo cuenta al pequeño Pepe Toño. Asimismo mediante el diálogo se descubre la situación actual, relacionada con Pepe Toño. El Tío Sergio se hizo amante de la madre del muchacho, y por esto su padre se fue de la casa. Finalmente, en el deseo de Tío Sergio de ser el nuevo papá de Pepe Toño, la historia se proyecta hacia el futuro, aunque impreciso (el final: "Pepe Toño se mantiene en silencio. Tío Sergio va a añadir algo, pero se arrepiente [...] Con Pepe Toño sentado hacia el vacío, inmóvil, conteniendo su rabia, el andamio comienza a elevarse, a elevarse, hasta desaparecer. Oscuro final"').

Los diálogos de Leñero, en general, incluyen gran cantidad de relatos contables, tal vez ésta sea la explicación de por qué se perciben

${ }^{19}$ Aquí se trata de la palabra tanto hablada como escrita.

${ }^{20}$ Pensamos que tiene mucha similitud con el género épico cuyo origen es pre-letrado. Tal vez, sería interesante desarrollar esta tesis. 
con tanta facilidad y sugestión. Se puede decir que es la narrativa amena del sentido común puesta en el escenario; la acción se enfatiza y se retrata. Con la retratación, el mensaje del autor asciende a la superficie de sus dramas y se vincula con la realidad vivida. El espectador se siente satisfecho por captar y digerir la estética teatral presentada de manera realista.

\section{Ibargüengoitia}

Afirmar que el teatro de Ibargüengoitia carece de elementos narrativos sería exagerar. Sin embargo, comparando su obra con la de Leñero, se hace evidente una tendencia contraria respecto a la acción. Más que describir historias, se retratan personajes, situaciones o entornos, como ya hemos anunciado. Pero si en prosa (cuento o novela) el retrato propiamente dicho sólo representa una parte del texto, frecuentemente subordinada a la trama-acción y restringida en su longitud, en las 'comedias' ${ }^{21}$ de Ibargüengoitia por el contrario se crea un retrato a lo largo de toda la pieza.

Esta tendencia se percibe primero a nivel formal. Una revista global de las páginas revela que las réplicas son muy cortas ${ }^{22}$ para que haya espacio suficiente de relatar un hecho. La mayoría de las réplicas relativamente largas corresponden a las descripciones de rasgos físicos o de carácter del personaje, hechos por él mismo, como podemos encontrar en Los buenos manejos:

Don Sebastián.- Mejor. Prosigo: mis cualidades personales están a la vista: soy elegante, mi rostro no es precisamente bello, pero tiene una cualidad varonil que lo hace muy apreciable; mis ojos son claros y penetrantes, lo que demuestra una conciencia tranquila y una firmeza que aterra a mis enemigos. Soy implacable con los pobres, benigno con

${ }^{21}$ La denominación de la mayoría de las piezas como comedias es del propio autor, tal vez, en relación a la obra de Balzac.

${ }^{22}$ El carácter entrecortado de los diálogos de Ibargüengoitia es muy semejante al discurso teatral de A. Chéjov. 
los ricos y un verdadero Némesis cuando se trata de castigar a los que violan las leyes que yo dicto. ¿Qué le parece?

Otro ejemplo es de una respuesta-descripción de El tesoro perdido:

Li Kia.- En la ciudad hay una gran crisis. Los trabajadores metalúrgicos están en huelga. La bolsa de valores está muy... deprimida. Mis amigos tienen apendicitis, amigdalitis, o salieron de viaje. De mis dos tíos ricos, uno tiene una hija enferma y el otro no me habla. Los bancos han suspendido los créditos a la construcción. Los padres de familia han hecho un gran mitin para protestar contra la inmundicia de los textos escolares. En resumen, Tou Wei, no puedo conseguir quinientas onzas de plata.

En realidad, las réplicas largas no son frecuentes en el teatro de Ibargüengoitia, es decir, prácticamente no hay monólogos; la mayoría de los enunciados ocupa uno o dos renglones en página impresa. Pensamos que este dato de alguna manera influye en el discernimiento de los espectadores y lectores. En tales condiciones, la atención debe estar activada y ser muy aguda a lo largo de los espectáculos que normalmente se realizan en tres actos y son bastante largos. Por lo mismo surge una pregunta pragmática: ¿El público está dispuesto a permanecer bajo una fuerte tensión intelectual, emocional y estética durante más de dos horas?

Desde la perspectiva del contenido, las 'comedias' no son fáciles de ser relatadas: el sentido de las obras se pierde mucho en tal intento. La trama fija las acciones en el tiempo y cuando éstas escasean es difícil hilarla. En nuestra opinión, el mayor interés de Ibargüengoitia se centra en exponer, más bien en pintar frente al auditorio, diversos retratos de la sociedad en que vive. Tal objetivo predetermina su estilo personal de dramaturgo, que se manifiesta en el predominio de las descripciones (donde aparece el entorno) en comparación con las acciones de los personajes.

La tesis propuesta permite crear ciertos dispositivos semánticos (o los significados connotativos) que 'aprueban' las descripciones y superan su aparente estatismo. Así, el convencionalismo artístico de 
las piezas se concibe evidente, lo que conduce finalmente a que el espectador alcance un alto nivel de conciencia semiótica. Desafortunadamente para Ibargüengoitia, los espectadores y lectores de su época ${ }^{23}$ no se habían proyectado hacia esta particularidad estilística del autor. Otra dificultad puede revelarse si nos referimos a los personajes, más bien a la conexión que se establece entre el espectador y los personajes.

En el apartado siguiente presentamos una especulación meramente teórica: ya han pasado casi cincuenta años desde la construcción de su teatro. Sin embargo, esta reflexión nos permite ampliar en parte un tema importante dentro de la pragmática de la teoría teatral.

\section{Comunicatividad escénica}

En el teatro la función comunicativa infiere de manera evidente. El discurso, los actores y el público se encuentran en el mismo espacio y coinciden en el tiempo. ${ }^{24} \mathrm{El}$ arte dramático pretende envolver al auditorio en su ambiente de espectáculo estableciendo un contacto directo y creando así una situación comunicativa, aunque muy particular. La diferencia se debe a que el teatro pertenece a los 'medios calientes', en términos de McLuhan: el espectador presencia los diálogos y no participa en ellos ni interviene a la par con los actores. A pesar de esto, el drama influye en el espectador de manera directa originando una especie de simulacro comunicativo: así lo muestra la reacción inmediata de algunos espectadores. Tal vez aquí influye mucho que el elenco (la presencia humana) constituye un efecto de implicación, muy diferente a la del libro o la película.

La relación comunicativa 'teatral' -más bien su realización-depende de ciertos presupuestos conceptuales. Curiosamente casi en el mismo período, dos teóricos por separado descubrieron y empezaron

${ }^{23}$ Desconocemos la situación de hoy.

${ }^{24}$ Reiteramos que si se trata del lector, todos los elementos mencionados se unen de manera virtual; si no, la lectura se asemeja con la lectura de libros. 
a considerarlos una parte ineludible de texto: Lotman en 1977 y Eco en 1979. (Aunque estos trabajos están traducidos en varios idiomas, todavía no hicieron ningún efecto notorio en la teoría, es decir, no se han desarrollado debidamente. $)^{25}$ Ambos trabajaron con el material narrativo y llegaron a la conclusión que resumimos de manera siguiente: aunque un texto es una construcción estructuralmente autónoma y su contenido se desarrolla según reglas internas, el escrito de cualquier manera encierra la figura de su receptor. Es interesante comparar sus tesis:

El texto contiene, en forma compactada, el sistema de todos los eslabones de la cadena comunicativa, y, del mismo modo que extraemos de él la posición del autor, basándonos en él podemos reconstruir también al lector ideal. ${ }^{26}$

Un texto postula a su destinatario como condición indispensable no sólo de su propia capacidad comunicativa concreta, sino también de la propia potencialidad significativa. En otras palabras un texto se emite para que alguien lo actualice. ${ }^{27}$

Como se observa, Lotman parte de la idea propiamente comunicativa $^{28}$ y Eco se refiere a una serie de competencias 'capaces de dar contenido a las expresiones que utiliza'. A pesar de las perspectivas diferentes ${ }^{29}$ y de términos distintos, ambos coinciden en la misma

${ }^{25}$ La misma pragmática interpretativa del texto la estudia Ricoeur, pero en su teoría (desde un horizonte distinto) no se refleja la concepción de Lotman y Eco, ni se refleja este aspecto de su teoría en otros trabajos; por lo menos no hemos encontrado nada al respecto.

${ }^{26}$ Iuri M. Lotman, La semiosfera I. Semiótica de la cultura y del texto, 1996, Madrid, Cátedra (edición de Desiderio Navarro), p. 113.

${ }^{27}$ Umberto Eco, Lector in fabula. La cooperación interpretativa en el texto narrativo, 1987, Barcelona, Lumen, p. 77.

${ }^{28}$ No sobrará una cita más: "[Hay que llamar la atención] sobre cómo el comunicado influye en el destinatario, transformando la fisonomía del mismo. Este fenómeno está vinculado al hecho de que todo texto (en particular, todo texto artístico) contiene lo que preferíamos llamar una imagen del auditorio, y de que esta imagen del auditorio influye activamente sobre el auditorio real", Iuri M. Lotman, La semiosfera I..., op. cit., p. 110.

${ }^{29}$ En realidad, las ideas son muy afines si examinamos sus trabajos, en particular el de Umberto Eco, op. cit., p. 80; y de Iuri M. Lotman, La semiosfera III..., op. cit., p. 57-84. 
exigencia de abstracción teórico-conceptual: la idea de 'imagen de auditorio', 'lector ideal' o 'lector modelo'. Para el proceso de construcción de un texto, y aún más si se trata de una obra artística, el concepto propuesto tiene potencial indudable.

La concepción del público modelo es de gran utilidad para la pragmática teatral, la creación y la puesta en escena de las obras. También es oportuna para examinar los efectos, positivos o negativos, de las piezas sobre el auditorio. Se sabe bien que los gustos son relativos y dependen mucho de las épocas, situaciones económicas y culturales. Sin embargo, una obra artística puede ser excluida o, por el contrario, apuntada en los repertorios teatrales con base en la opinión del público, entendido éste en términos generales, ${ }^{30}$ como lo proponen Eco y Lotman. En caso negativo de no aceptación de una obra, se crea un conflicto entre el autor y el público que puede tener las consecuencias lamentables para la cultura en un momento dado.

\section{Ibargüengoitia}

Como hemos mencionado, Ibargüengoitia renunció al oficio de dramaturgo. Sus propias palabras conducen a la sospecha de un conflicto entre su teatro y la recepción de éste por parte del público. Si el auditorio no siempre lo percibe de manera consciente y simplemente rechaza el producto escénico, el autor, por lo general empieza a razonar en torno al origen del desconcierto:

[...] el público estuvo muy por debajo del teatro que se le dio. Es necesario que el espectador vaya aprendiendo su lugar. [...] Necesitamos un público que sepa a lo que va y, sobre todo, que tenga una capacidad de adaptarse a lo que está viendo. ${ }^{31}$

\footnotetext{
${ }^{30}$ Los directores y censores también forman parte del público.

${ }^{31}$ Jorge Ibargüengoitia, op. cit., p. 79-80.
} 
A fin de cuentas, se trata de un obstáculo serio, de la discrepancia comunicativa entre el autor y su espectador: el receptor no capta el mensaje del espectáculo ni el de su autor. Entonces surgen las interrogantes: ¿Por qué no se estableció el contacto (ideal, a nivel de comprensión) entre las 'comedias'y el auditorio? ¿En qué no correspondió el público del teatro de Ibargüengoitia a sus expectativas? También se puede invertir la pregunta, aunque pensamos que la respuesta será la misma. Aquí, el concepto del público modelo adquiere una dimensión explicativa.

Es suficiente un análisis somero para revelar que Ibargüengoitia tiene muy precisa la imagen de su auditorio, bastante concreto y determinado. ${ }^{32}$ Lo que retrata fielmente (el principio realista lo exige) es el público en la sala. Aún más, se lo expone desde el lugar más iluminado del teatro. En otras palabras, el autor crea un espejo para el espectador y lo instala en el escenario. De esta manera, el público observa su propia imagen proyectada por el cristal del escenario.

En Ibargüengoitia, esta imagen (no olvidemos, ideal, modelo) no se diferencia mucho de una obra a la otra y, hablando a grandes rasgos, sólo se cambian la edad y el sexo, pocas veces la nacionalidad y la época. Pero los demás semblantes de la fisonomía de los protagonistas se parecen asombrosamente. Un elemento constante y el más importante para el dramaturgo, corresponde al estatuto cultural y a una actitud -conformista- de los personajes. El mayor incentivo de los mensajes estético-artísticos y culturales del autor se puede vincular con la postura del hombre retratado frente a la vida cotidiana, que es en cierto sentido arreglada y acomodada, aunque no cautivadora. Sin embargo, durante varias horas el espectador se guía hacia su propia imagen, que finalmente intuye y enfrenta desaprobándola con un rechazo (¿involuntario?) de la obra. Empero el retrato aparece generalizado y sin ningún determinismo particular.

A pesar de un conflicto obvio, el acto comunicativo entre el discurso teatral y el público se cumple cabalmente. El espectador se siente

${ }^{32}$ Es de notar que los personajes de Ibargüengoitia no varían mucho, pertenecen al mismo grupo económico-social y cultural. 
involucrado físicamente en el espectáculo, tal vez con demasía (¿de dónde proviene la fuerza de su repudio?) y discierne el veredicto del autor. En tales circunstancias - se puede razonar- la conducta y sensación del espectador (nos referimos a la negación y rechazo de lo que el autor le pretende comunicar) surgen casi de manera irreflexiva: él mismo no es competente para explicar su reacción.

Pensamos que el meollo del asunto está en el propio mensaje del autor. Su juicio, oculto detrás de los diálogos-retratación, es bastante severo, y además ingrato para el espectador. La imagen que llega a los sillones de la sala no es bella ni puede atraer: en la escena actúan héroes que en la vida real no pueden ser ejemplares (por su mediocridad, indiferencia o aburrimiento de la vida) ni resultan simpáticos como personas.

Tal parece que Ibargüengoitia es un autor que crea anti-héroes. Primero, a nivel de los caracteres de sus personajes, como acabamos de explicar. Segundo, por una razón estructural: sus protagonistas no son jerarquizables de manera tradicional con un centro y periferia. Prácticamente en todas las piezas varios personajes juegan a la vez el papel principal, creando así, pensamos, a sólo un protagonista: un prototipo, nutrido y solidificado por los demás, que interviene en la pieza. Aun en la 'comedia' Pájaro en mano de 14 personajes, la figura de Policía con su única frase a lo largo de la pieza: "Oiga, falto yo". (Raymundo le da dinero.) "Gracias, caballero" (sale), agrega una porción significativa, asimismo reveladora, a la imagen del protagonista-prototipo de la obra.

Lo característico (y triste, agregamos) es que la mayoría de los protagonistas son jóvenes. Además -y es lo que adivina el público-este retrato, un artístico reflejo de la vida, es muy familiar para el espectador y también pertenece a $s u$ vida; sólo que, iluminado en el proscenio no luce y se le expone transfigurado por la idea artístico-ética del autor, evidentemente, bastante escéptica. ${ }^{33}$

${ }^{33}$ En este trabajo no pretendemos hacer un análisis de obras ni demostrar esta idea con material concreto de las piezas. Se puede vigorizar la certeza (o suspicacia) de esta afirmación en la propia lectura de las 'comedias' de Ibargüengoitia. 


\section{Leñero}

Vicente Leñero también es sin duda alguna un maestro en el arte realista: hace creer al público en la autenticidad de lo que sucede en el escenario. Asimismo, su obra resulta ser un espejo del teatro de la vida. Sin embargo y a pesar de una tendencia crítica (sus protagonistas tampoco representan héroes a seguir, como en el teatro de Ibargüengoitia) el auditorio, al igual que el lector, presencia sus espectáculos de manera mucho más placentera y vivaz. ¿A qué se debe?

Una larga reflexión nos condujo a la siguiente explicación. El público de Leñero - del mismo estrato cultural que el de Ibargüengoitia-no se identifica con los personajes teatrales. Más aún, no le es factible hacerlo por razones naturales: la mayoría de los protagonistas pertenece a las capas económico-social-culturales o profesionales disímiles a los del espectador habitual. En consecuencia, lo que se observa desde la sala, es la vida de otros, distante y ajena. Descubrirla, asombrarse o criticarla es mucho más fácil que analizar y juzgar lo que se vive personal y cotidianamente.

Por otro lado, el público asiste al teatro en un estado cándido y crédulo en demasía. Es algo bastante frecuente y no sólo en el ambiente teatral. Viene a la mente un incidente del escritor Severino Salazar quien comentó que en una de las presentaciones de su libro Donde deben estar las catedrales, una persona lo acusaba de escribir sobre sus familiares y descubrir su vida privada. Más aún, la gente del pueblo -Tepetongo, Zacatecas- se sintió ofendida al leer el libro y reconocerse en él.

Eco describe esta sencillez con los términos de 'lector ingenuo', que no es capaz de llegar a los procedimientos interpretativos ni captar el metatexto. Asimismo siempre está expuesto a una trampa y a las aberraciones textuales. ${ }^{34}$ También en Lotman se enuncia con amonestación:

${ }^{34}$ Umberto Eco, op. cit., p. 274-78. 
La cultura es inseparable de los actos de conciencia y de autoconciencia. La autoevaluación es un elemento indispensable de la misma. ${ }^{35}$

Está claro que la franqueza y naturalidad en la percepción de arte puede consagrar el desenvolvimiento estético del propio espectador y marginar la cultura. A propósito de esto Ibargüengoitia reflexiona:

Sea porque somos un pueblo joven, o porque así está el mundo, el caso es que hemos sustituido la función de apreciación artística, que requiere ciertas condiciones físicas y mentales, por la función de clasificación, que en resumidas cuentas no requiere sino el aprendizaje de ciertos slogans, y que permite abrirse paso en la sociedad, tener temas de conversación, ganar amigos entre los del propio partido y enemigos entre los del contrario, y hasta escribir tratados extensos sobre cualquier asunto relacionado con el arte. ${ }^{36}$

El llamado del escritor no necesita comentarios adicionales. El proceso comunicativo es de doble cara y depende en la misma medida tanto del dramaturgo como del auditorio. En el contexto donde la obra sigue perteneciendo al autor y se somete a las reglas jurídico-culturales, es el escritor, y en particular el teatral, quien empieza el diálogo y el público tiene que responderle de manera adecuada.

\section{A manera de coda}

Consideramos que en la percepción de una obra dramática-solitariamente leída o contemplada en público- es importante tener en cuenta que ésta, como cualquier producción artística, implica el desarrollo de ciertas habilidades. El ejemplo de la comparación entre la obra teatral de Ibargüengoitia y la de Leñero es suficiente para vislumbrar el papel del espectador (del lector-espectador virtual) quien finalmente tiene

${ }^{35}$ Iuri M. Lotman, La semiosfera I..., op. cit., p. 244.

${ }^{36}$ Jorge Ibargüengoitia, op. cit., p. 72. 
que responsabilizarse por el diálogo con el autor, al igual que por su propia idiosincrasia aplicada al terreno cultural. En caso contrario, el juicio de la obra puede convertirse en un cúmulo de calificaciones intuitivas, carentes de sostenes intelectuales y estéticos. Esto es lo que realmente tuvo lugar en el teatro en un pasado cercano.

Frecuentemente se produce la situación de que cuando el público ha sido vulnerable a las peripecias teatrales presentadas de un modo muy real pero artificioso sólo percibe la superficie de una obra. Se puede desenmarañar esta situación en vista de dos factores. Por un lado, el espectador que puede ser privado de un sentido imparcial en relación consigo mismo. Es una actitud totalmente acrítica y narcisista. ${ }^{37}$ Por otro lado, el espectador no logra contener y analizar las sensaciones espontáneas al encontrarse frente a un fenómeno de arte. Esto a su vez se debe a que su competencia semiótica no está suficientemente desarrollada. ${ }^{38}$ Las consecuencias son evidentes, sin olvidar que 'en el arte cuanto más simple, tanto más complejo’, en palabras de Lotman.

${ }^{37}$ Narcisista, con el significado que le dio McLuhan hablando no tanto sobre autoadoración, como sobre la narcosis, entumecimiento, insensibilidad en las percepciones (v. el capítulo "El amante de juguete. Narciso como narcosis" en: Comprender los medios de comunicación).

38 "La comprensión del arte, dice Lotman, es el dominio de la medida de su convencionalidad. Las violaciones en esta esfera conducen a un efecto de incomprensión”, Iuri M. Lotman, La semiosfera II..., op. cit., p. 241. 